\title{
Article
}

\author{
가막만의 빈산소 퇴적층 형성과 저서성 유공충 군집변화 연구

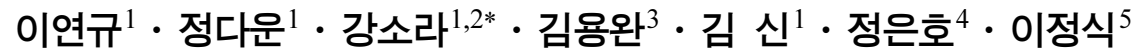 \\ 1전남대학교 수산해양대학 해양기술학부 \\ (550-749) 전남 여수시 미평로 386 \\ 2부산대학교 지질재해산업자원연구소 \\ (609-735) 부산 금정구 장전동 산 30 \\ 3전남대학교 공동실험실습관 \\ (550-749) 전남 여수시 미평로 386 \\ 4국립해양조사원 서해해양조사사무소 \\ (325-903) 전남 서천군 장항읍 신창리 164-3 \\ 5 전남대학교 수산해양대학 수산생명의학과 \\ (550-749) 전남 여수시 미평로 386
}

\section{The Formation of Hypoxia Sediment and Benthic Foraminiferal Change in Gamak Bay, Southern Coast of Korea}

\author{
Yeon Gyu Lee ${ }^{1}$, Da Un Jeong ${ }^{1}$, Sora Kang ${ }^{1,2 *}$, Yong Wan Kim³ ${ }^{3}$, Shin Kim', \\ Eun Ho Jung ${ }^{4}$, and Jung Sick Lee ${ }^{5}$
}

${ }^{1}$ Faculty of Marine Technology, College of Fisheres and Ocean Science, Chonnam National University Yeosu 550-749, Korea

${ }^{2}$ Geologic Hazard \& Industrial Resources Research Institute of Pusan National University Busan 609-735, Korea

${ }^{3}$ Center for Research Facilities, Chonnam National University

Yeosu 550-749, Korea

${ }^{4}$ Korea Hydrographic and Oceanographic Administration

Seocheon 325-903, Korea

${ }^{5}$ Department of Aqualife Medicine, College of Fisheres and Ocean Sciences, Chonnam National University Yeosu 550-749, Korea

\begin{abstract}
In order to understand the relationship between the formation of hypoxia sediment by eutrophication and changes in benthic foraminiferal assemblage, micropaleontological and geochemical analyses were carried out on one sediment box core (K-1) recovered in the northern Gamak Bay, which is one of the aquacultural areas in the South Sea of Korea. In this analysis, the PON content in the sediment rapidly increased, while the $\mathrm{C} / \mathrm{N}$ ratio and the $\mathrm{C} / \mathrm{S}$ ratio decreased since 1977 . These results indicate that eutrophication commenced in 1977 in the northern Gamak Bay, and consequently, the hypoxia sediment is $20 \mathrm{~cm}$ thick. Ammonia beccarii-Buccella frigida assemblage occurs before the formation of hypoxia sediment. Trochammina hadai-Buccella frigida assemblage appeared in the transitional period toward hypoxia and Trochammina hadai assemblage with a low abundance and diversity is observed in the hypoxia sediment. The agglutinated species $T$. hadai is regarded as a bio-indicator (opportunistic species) of the organic pollution in northern Gamak Bay.
\end{abstract}

Key words : hypoxia, eutrophication, benthic foraminifera, Trochammina hadai, bio-indicator

\footnotetext{
*Corresponding author. E-mail : sora@pusan.ac.kr
} 


\section{1. 서 론}

우리나라 연안 해역은 생활하수 및 산업 오폐수 유입, 다양한 양식 활동에 의한 자가오염의 증가로 극도의 유기 물 집적이 이루어지고 있다(Kang et al. 1993). 특히 남해 안은 리아식 해안으로 해안선이 복잡하며 내만이 발달하 여 조류소통과 해수교환이 원활하지 못하며 하계에 강우 유입과 표층수온 증가에 의해 밀도약층이 빈번하게 형성 된다. 하계의 성층화된 내만수괴에 의하여 저층에 산소공 급이 제한되며, 표층에서 대규모로 발생한 식물플랑크톤 이 침강하여 미생물에 의해 분해되면서 산소 소비를 촉진 시켜 저층에 빈산소 해역을 형성한다(Hong 1987; Kang 1991; 김과 김 2003; Lim et al. 2006). 한국 남서해역의 수질은 매우 양호한 것으로 나타나나 퇴적층 내에는 유기 오염이 심각한 것으로 보고되고 있다(윤 2010). 특히 남해 연안 중앙부에 위치한 가막만은 만 입구가 매우 좁은 반 폐쇄적인 만으로서, 만 북측은 지형적으로 오목한 해저지 형을 이루며, 해수유동이 매우 미약한 지역이다(Fig. 1). 주변 하천으로부터 유기물 유입이 지속적으로 발생하며,

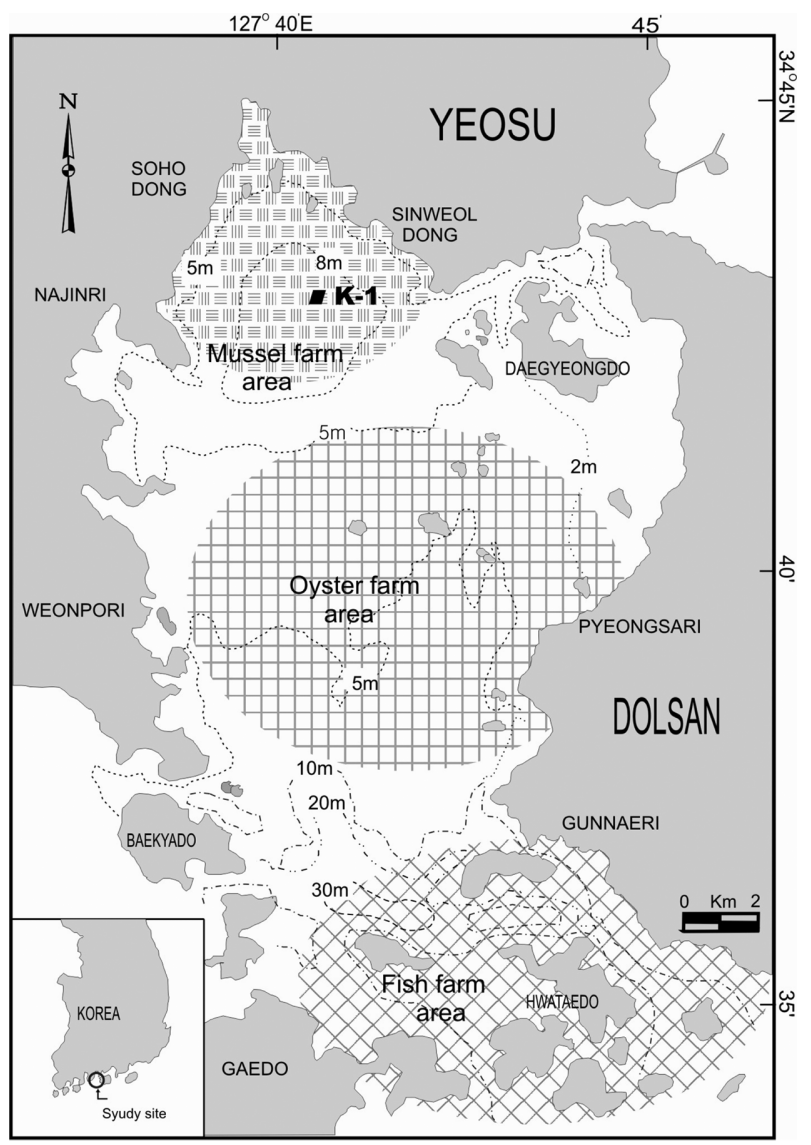

Fig. 1. Map showing sampling station (K-1) with bathymetry, and distribution of the aquaculture ground in the Gamak Bay
하계 강우 시에는 많은 양의 담수와 함께 입자성 유기물 이 유입, 분해되면서 저층 용존산소를 소비하게 되어 빈산 소수괴가 빈번히 발생하는 해역이다(문 등 2006; 노 등 2006; 김 등 2006; 오 등 2009).

해양에서 영양분의 빠르고 지속적인 증가로 인한 부영 양화는 초기단계에는 저서생태계에 긍정적인 영향을 미치 나 저층으로 운반되는 입자성 유기물과 퇴적물내의 유기 물 분해 시 저층의 용존산소가 소비되면서 산소 결핍을 초래하여 빈산소층(용존산소 $<2 \mathrm{mg} / \mathrm{l})$ 을 형성하게 되어 많은 저서성 진핵생물(eukaryote benthic organisms)의 서 식에 악영향을 미친다(Arai 2001; Boesch et al. 2001; Cloern 2001). 부영양화와 빈산소층의 형성은 저산소 조건 에서도 내성이 강한 소형의 퇴적물 습식 다모류와 같은 일부 기회종들만 극단적으로 출현하는 높은 밀도/낮은 종 다양도의 군집을 형성한다(Gray 1992; Gray et al. 2002). 주변환경에 민감한 종들은 환경이 변화되면(오염, 빈산소 층 형성 등) 사라지게 되지만, 변화에 대한 내성(저항성)이 높은 종들은 오히려 개체수가 증가하는 경향을 보인다. 일 반적으로 오염해역의 기회종(opportunistic species)은 이 러한 내성을 가지고 번성하는 종들을 의미한다(Alve 1995a). 또한 기회종은 각 해역의 오염의 원인(하수, 양식, 유류 등)에 따라 다르며, 같은 오염원이라 하더라도 해역 의 특성(지형적, 수리적, 물리적 조건 등)에 따라 달라진다 (Alve 1995a).

유공충은 원생동물(Protozoa) 중 위족충류(Sarcodina)에 속하며, 캄브리아기에 출현하여 오랜 지질시대를 거쳐 현 재에 이르는 종으로서 생태적으로 저서성 유공충(benthic foraminifera)과 부유성 유공충(planktonic foraminifera)으 로 구분된다. 과거 유공충은 주로 지질학적 제현상(순차층 서, 고환경해석, 고해양학, 과거해수면 및 기후변화)을 이 해하고자 하는데 주요한 연구대상으로 사용되어 왔으나, 저서성 유공충이 연안환경 오염을 추적하는 지시자로 알 려진 이후, 현재 해양에서 발생하는 해양오염의 유용한 생 물지시자로 활용범위가 확대되고 있다(Alve 1995a; Scott et al. 2001; Murray 2006). 산출량이 풍부하고, 종조성이 환경변화에 따라 다양하게 나타나는 저서성 유공충은 수 온 염분과 같은 자연환경요소 뿐만 아니라 오염, 부영양화 등에 의해 나타나는 현상에 대해서도 매우 민감하게 반응 하며(Yanko et al. 1999; Murray and Alve 2002), 해양오 염 중 중금속 오염(Yanko et al. 1998; Samir and El-Din 2001; Frontalini and Coccioni 2008), 유류(oil) 오염 (Morvan et al. 2004; Ernst et al. 2006) 및 부영양화 (Thomas et al. 2000; Thibodeau et al. 2006; Rabalais et al. 2007; Mojtahid et al. 2008, Tsujimoto et al. 2006a, $2006 \mathrm{~b}, 2008)$ 등의 연구에서 유용한 생물지시자(bioindicator)로 활용되고 있다. 우리나라에서는 마산만(우 등 
1999)과 대산공업단지(우 등 2000) 주변해역에서 중금속 오염과 저서성 유공충 종조성 변화 연구가 수행된 바 있 다. 더욱이 저서성 유공충의 각은 퇴적물 내 보존성이 뛰 어나 주상퇴적물을 이용하여 수십 수백년 전부터 현재까 지의 해양환경변화 및 오염의 역사를 파악할 수 있는 추 적자로 활용된다(Hayward et al. 2004; Platon et al. 2005; Tsujimoto et al. 2006a, 2008).

본 연구에서는 남해연안에서 대표적으로 부영양화에 의 한 빈산소 현상이 빈번하게 발생하는 가막만 북측해역에 서 주상퇴적물시료를 채취하고 ${ }^{210} \mathrm{~Pb}$ 를 이용한 퇴적연대 측정, $\mathrm{C}, \mathrm{H}, \mathrm{N}$ 및 $\mathrm{S}$ 원소분석과 저서성 유공충의 종조성 변화를 분석하여, 가막만 북측해역의 부영양화에 의한 빈 산소 퇴적층 형성과 이에 반응하는 저서성 유공충 지시자 를 파악하고자 한다.

\section{2. 연구지역}

가막만은 리아식 해안이 발달한 남해안 가운데 위치하 고, 동측으로 돌산도 서측으로 고돌산반도, 남쪽으로는 개 도 등 여러 섬들로 둘러싸인 반폐쇄적인 해역으로서, 남북 방향 길이 약 $15 \mathrm{~km}$, 동서방향 약 $9 \mathrm{~km}$ 인 타원형으로, 평 균수심 $9 \mathrm{~m}$ 의 천해이다(Fig. 1). 수심은 만 중앙으로부터 남쪽으로 갈수록 차츰 깊어져 만의 남쪽 입구에서는 수심 이 $30 \mathrm{~m}$ 에 이른다. 그리고 만 동측에서 서측으로 다소 깊 어지는 경향을 보이며 만의 북측지역에서는 오목한 해저 지형을 갖는다.

가막만에서 조류흐름은 만 북측을 제외한 남측, 북동 및 중앙부 해역에서는 밀물, 썰물시에만 남측입구 및 북동 수로를 통한 해수교환이 일어나며, 만 북측해역에서는 흐 름이 극히 매우 미약하고 거의 정체된 상태(Lee and Kim
2009)를 보이며, 만내의 해수유동에 의해 물질이 수렴되는 곳이다(Fig. 2).

가막만의 퇴적물은 대경도와 여수항 사이의 북동쪽 수 로 지역에서 점토질 모래로 구성된 비교적 조립질 퇴적상 이 나타나나, 전반적으로 평균입도 6 9 Ø 점토질 실트의 세립질 퇴적상으로 구성되어 있다(이 등 1995).

가막만은 생물생산성이 높아 다양한 양식활동이 이루어 지고 있는 해역으로서, 북측 내만역은 홍합양식, 북동쪽 대경도 주변해역은 살포식 피조개 양식, 만 중앙부에는 굴 양식 그리고 만 남측 입구해역에는 가두리 어류양식이 집 단화되어 있다. 특히 북측 내만역은 생활하수와 양식부산 물 등에 의해 부영양화가 진행되어 고수온기 저층해수에 빈산소층 형성과 적조발생 등 다양한 환경문제를 발생시 키고 있다(문 등 2006; 노 등 2006, 김 등 2006; 오 등 2009).

\section{3. 연구방법}

본 연구에서는 시료채취 시 퇴적층 교란을 방지를 위하 여 박스코어(box corer: $25 \times 25 \times 30 \mathrm{~cm}$ )를 사용하였으며, 박스코어 내에서 총길이 $28 \mathrm{~cm}$ 의 주상시료(내경: $69 \mathrm{~mm}$ ) 를 3 개 채취하여 입도 및 원소분석, 유공충 시료채취 및 연-엑스선(soft-X ray) 촬영, ${ }^{210} \mathrm{~Pb}$ 을 이용한 퇴적속도를 측정하였다. 주상시료 채취 시 퇴적층에 대한 압밀이 일어 나지 않도록 매우 천천히 적은 힘을 가하여 주상시료를 채취하였다. 퇴적물 입도 및 원소분석, 유공충 시료는 $2 \mathrm{~cm}$ 간격으로 채취되었으며, 각 측정 방법은 다음과 같다.

퇴적물 입도분석은 Ingram (1971)의 분석법에 따라, $10 \%$ 의 과산화수소 $\left(\mathrm{H}_{2} \mathrm{O}_{2}\right)$ 로 유기물을 제거하였고, $0.1 \mathrm{~N}$ 의 염산 $(\mathrm{HCl})$ 을 사용하여 탄산염을 제거하였다. 그리고
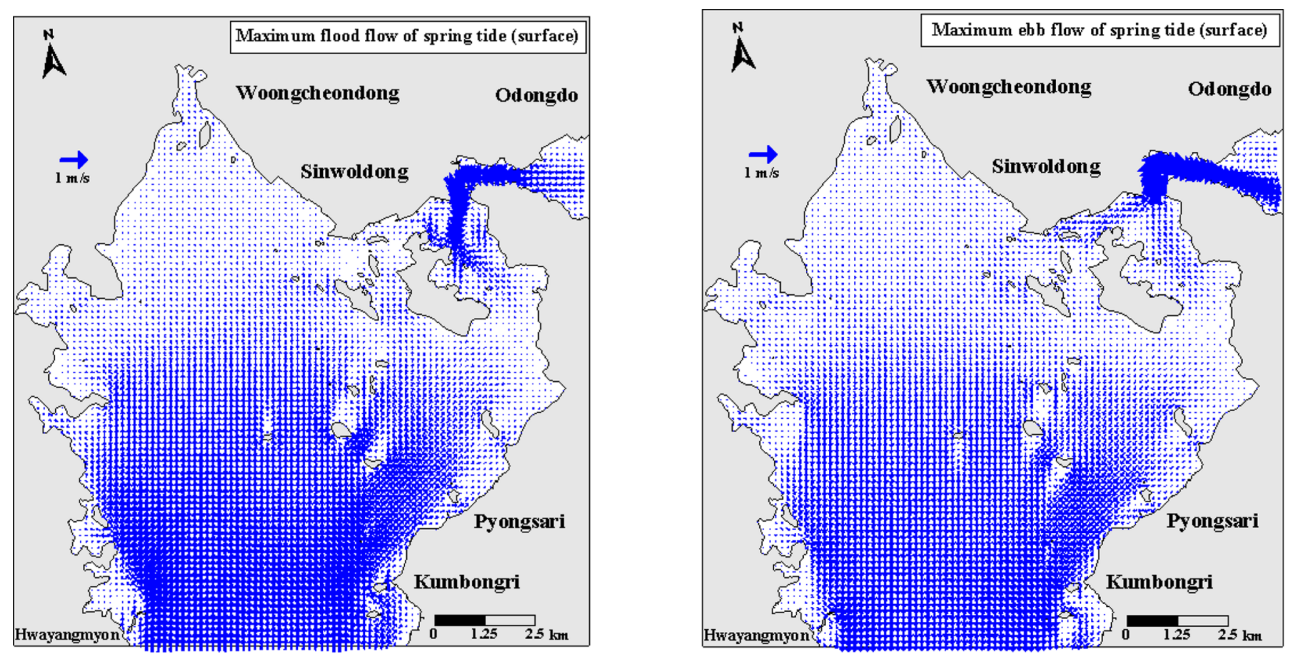

Fig. 2. Tidal flow vector diagrams for the strongest flood and ebb flows at the surface layers in Gamak Bay 
$4 \phi(0.0625 \mathrm{~mm})$ 체를 이용한 습식체질로 조립질과 세립질 시료로 분리하였다. 조립질 시료는 건조기에서 건조시킨 후 표준체를 이용한 건식 체질을 하여 입도별로 무게를 구하였고, 세립질 시료는 X-선 자동입도분석기(Sedigraph 5100 )로 입도의 백분율을 구하였다. 세립질 분석 시 확산 제는 $0.1 \%$ 칼곤(Sodium hexametaphosphate)을 사용하였 고, 입자크기는 $1 \phi$ 간격으로 분석하였다. 분석된 조립질과 세립질 퇴적물의 입도 등급별 무게 백분율을 Folk (1968) 방법에 따라 산출하였다.

POC(particulate organic carbon, 입자성 유기탄소), $\mathrm{PON}$ (particulate organic nitrogen, 입자성 유기질소) 측정 방법은 다음과 같다. 우선 퇴적물 습시료 약 $10 \mathrm{~g}$ 을 $110^{\circ} \mathrm{C}$ 에서 24시간 건조시켜 막자사발을 이용하여 균질화 한다. 균질화 한 건조시료에 $1 \mathrm{~N} \mathrm{HCl}$ (염산) $10 \mathrm{ml}$ 를 첨가하여 저질에 있는 탄산염을 제거한다. 그리고 남아있는 산을 제 거하기 위해 순수를 넣어 혼합한 후 원심분리를 실시하여 완전히 산을 제거하여 제차 $110^{\circ} \mathrm{C}$ 에서 24시간 건조시킨 다. 건조된 시료를 다시 균질화를 시킨 후 CHNS Element Analyzer(EA-1110)를 이용하여 측정하였다.

저서성 유공충 분석은 $2 \mathrm{~cm}$ 간격으로 $2 \mathrm{ml}$ 의 퇴적물을 채취하여, $4 \phi$ 체로 습식체질 하여 세립질 퇴적물을 제거한 뒤, 체에 남은 잔류물을 $45-60^{\circ} \mathrm{C}$ 온도의 건조기에서 건조 시켰다. 완전히 건조된 시료는 미량분리기(microspliter)를 이용하여 정량 세분하였으며, 실체현미경(SZ-ST Olympus Japan) 하에서 세립한 붓을 사용하여 200-300개체까지 추 출하였다. 종 동정 및 분류는 도감 및 문헌(Asano 1950a-e; Matoba 1970; Kang 2003)을 사용하여 실시되었다. 그리 고 $\mathrm{SEM}(\mathrm{Scanning}$ Electron Microscope, S-3000N)을 이용 하여 사진촬영, 미세구조를 파악하여 동정에 활용하였다. 정량분석은 시료 $20 \mathrm{ml}$ 당 산출된 저서성 유공충의 개체수 (abundance; Number of benthic foraminiferal individuals/ $20 \mathrm{ml}$ ), 총유공충 개체수에 대한 부유성 유공충 개체 비율 (P.F./T.F.; Planktonic foraminiferal individuals/Total foraminiferal individuals), 종다양도(species diversity) 및 균등도(evenness) 등에 대해 실시하였다. 종다양도는 다음 과 같은 Shannon and Weaver (1949) 계산식으로서, $S$ 는 출현종수를, $P i$ 는 총 출현 개체수 $(N)$ 에 대한 $i$ 번째 종의 출현 $(N i)$ 비율을 나타낸다.

$$
H(S)=-\sum_{i=1}^{S} P_{i} \times \operatorname{In} P_{i}
$$

균등도는 다음과 같은 Pielou (1966) 계산식을 이용하 였다.

$$
J=\frac{H(S)}{\operatorname{In}(S)}
$$

그리고 군집분석을 위하여 Bray-Curtis 유사도 지수를 이용하여 Cluster analysis를 실시하였다. 퇴적속도 측정을 위한 ${ }^{210} \mathrm{~Pb}$ 분석은 $1 \mathrm{~cm}$ 간격 24 개 정점에서 시료를 채취 한 후, 한국기초과학지원연구원 환경과학연구부(Korea Basic Science Institute)에서 수행되었다.

\section{4. 결과 및 토의}

\section{퇴적물 조성과 퇴적속도}

주상시료 퇴적물은 평균입도 약 $10 \phi$ 의 점토질로서 전 반적으로 균일한 입도변화를 보이며, 실트질 점토(silty clay) 퇴적상으로 구성된다(Fig. 3a). 연-엑스선 사진 촬영 결과(Fig. $3 \mathrm{~b}$ ), 하부층에서 일부 패류 파편들이 분포하나 부분적으로 엽리가 발달하며, 생물교란 현상은 나타나지 않는다.

퇴적속도 측정을 통한 퇴적연대의 결정은 해양오염변화 를 추적하는데 있어서 필수적으로 수행되며, 방사성 납 $\left({ }^{210} \mathrm{~Pb}\right)$ 을 이용한 방법이 주로 사용된다(Matsumoto 1981). ${ }^{210} \mathrm{~Pb}$ 의 반감기는 22.2 년이며, 퇴적물 중 ${ }^{210} \mathrm{~Pb}$ 의 연직분포 로부터 퇴적속도를 구하게 된다. 반감기의 약 5 배가 연대 측정 한계이므로 약 20-150년 정도까지 퇴적연대를 측정 할 수 있다. 본 연구지역에서 채취한 주상시료에 대한 ${ }^{210} \mathrm{~Pb}$ 분석 결과는 Fig. 4 와 같다. 누적중량에 대한 ${ }^{210} \mathrm{~Pb}$ 의 과잉 활동도(excess activity)의 직선기울기로부터 계산 된 주상시료 퇴적물의 퇴적속도는 $0.64 \mathrm{~cm} / \mathrm{yr}$ 이다. 일정 깊이 퇴적물의 퇴적연대는 그 깊이까지의 퇴적입자의 누 적중량을 퇴적속도로 나누어서 얻어진 년 수를 시료채취 년대로부터 제외하면 된다. 즉 시료깊이 $24 \mathrm{~cm}$ 까지는 약 37년이고, 연대로는 1971년에 해당된다. (a)

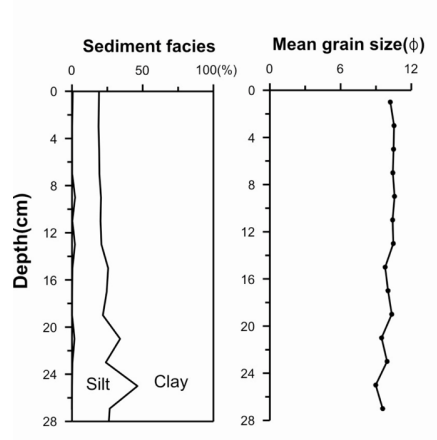

(b)

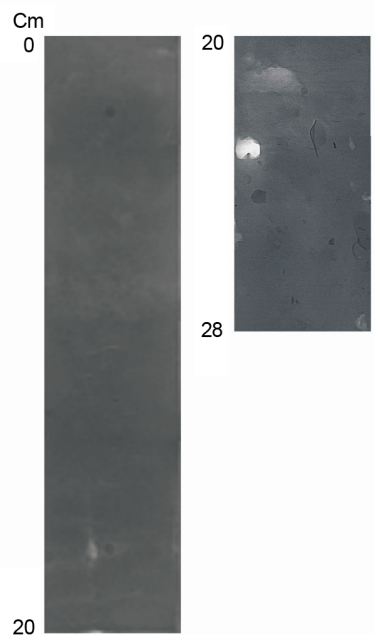

Fig. 3. Sediment grain size composition (a) and internal structure (b) of core sediment (K-1) 


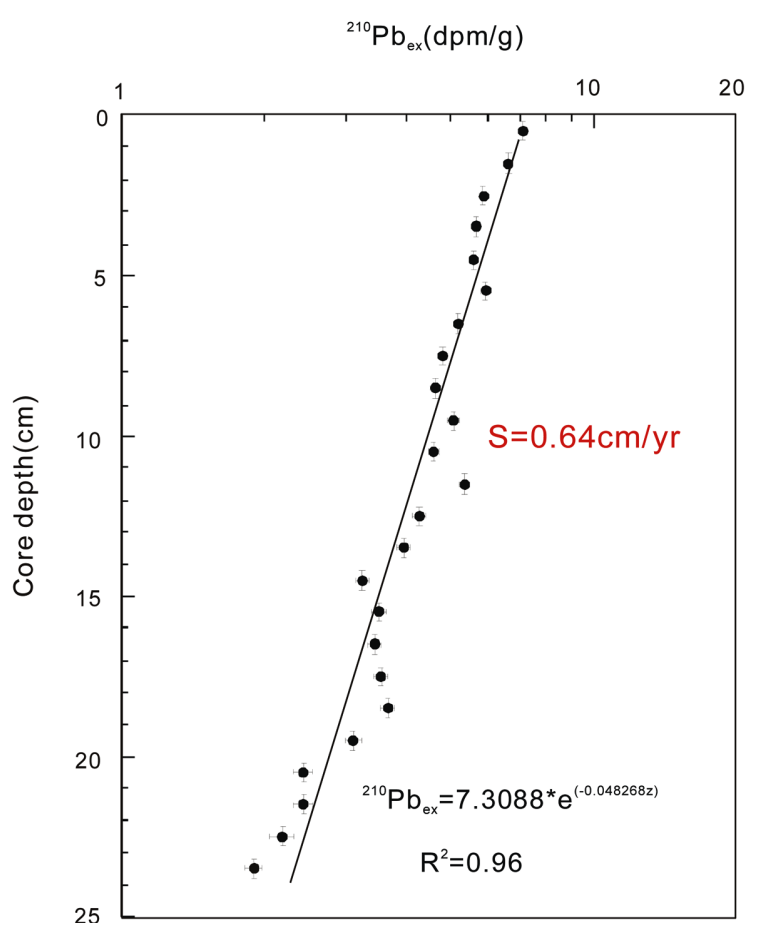

Fig. 4. Sedimentation rate (S) calculated from the radioactivity ${ }^{210} \mathrm{~Pb}$ measured in the core sediment at $1 \mathrm{~cm}$ intervals

\section{부영양화}

주상시료 퇴적물을 대상으로 측정된 $\mathrm{POC}, \mathrm{PON}$ 및 $\mathrm{C} / \mathrm{N}, \mathrm{C} / \mathrm{S}$ 비율 변화를 도시하면 Fig. 5 와 같다. $\mathrm{POC}$ 의 함 량분포는 $1.02 \sim 1.85 \mathrm{mgC} / \mathrm{g}$-dry(평균 $1.49 \mathrm{mgC} / \mathrm{g}$-dry)이 며, $\mathrm{PON}$ 의 함량분포는 $0.02 \sim 0.27 \mathrm{mgN} / \mathrm{g}$-dry(평균 0.17 $\mathrm{mgN} / \mathrm{g}$-dry)이다. $\mathrm{POC}$ 및 $\mathrm{PON}$ 의 연대별 변화 양상을 보 면, 1966년부터 1977년(퇴적물 깊이 $20 \mathrm{~cm}$ )까지 증가하 고 이후부터는 다소 안정된 상태를 갖는 형태로서 전반적 으로 비슷한 변화양상을 보인다(Fig. 5a). 이들 중 특히 $\mathrm{PON}$ 은 1977 년 이후 $0.27 \mathrm{wt} \%$ 로 급증한다. 질소 $(\mathrm{N})$ 는 인 (P)과 더불어 부영양화의 대표적 영양염류로서 바다의 광 에너지를 합성할 수 있는 유광층에서 생산자가 필요로하 는 수요만큼 공급되지 않아, 생산자의 성장에 종종 제한인 자로 작용하며, 이들의 증가는 주로 인위적 활동결과에 기 인하는 것으로 알려져 있다(윤 2010).

C/N 비율을 보면(Fig. 5b), 1966년부터 1977년까지는 53.78 17.01의 높은 비율을 보이며 저층에서 상부로 향하 여 점진적으로 낮아지는 경향을 보인다. 1977년 이후는 5.24 9.05의 다소 낮은 비율로 거의 일정하게 나타나고 있 다. $\mathrm{C} / \mathrm{N}$ 비율은 유기물질의 공급원을 추정하는데 용이한 것으로 알려져 있다(Müller 1977; Sampei and Matsumoto 2001). 일반적으로 공급원이 해양의 부유생물일 경우는 $\mathrm{C} / \mathrm{N}$ 비율이 6 9, 육지기원일 경우는 15 이상으로 알려져

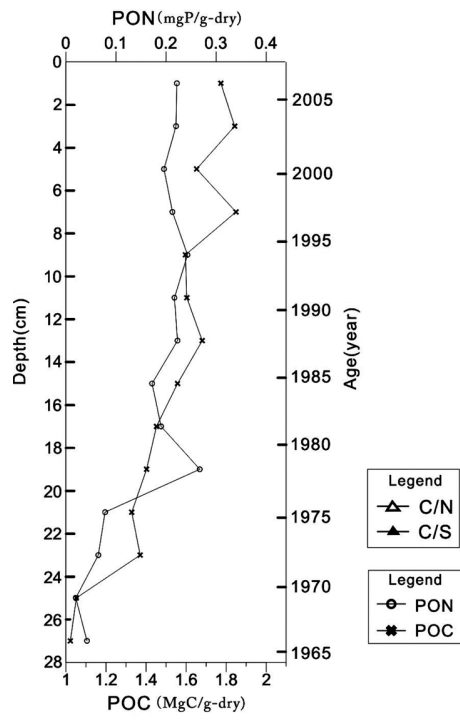

(a)

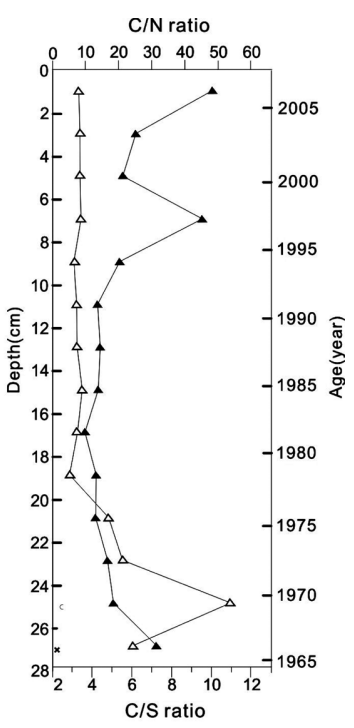

(b)
Fig. 5. Temporal variation of (a) POC (particulate organic carbon), PON (particulate organic nitrogen) and (b) $\mathrm{C} / \mathrm{N}$ and $\mathrm{C} / \mathrm{S}$ ratio

있다(Bordowskiy 1965a, 1965b). 본 연구지역에서 $\mathrm{C} / \mathrm{N}$ 비 율을 보면, 1977년 이전에는 육지로부터 많은 유기물질들 이 공급되었으나 이후에는 해역에 서식하는 식물 플랑크 톤 등과 같은 부유생물들로부터 공급 집적된 것으로 해석 된다.

C/S 비율은(Fig. 5b) 1965년부터 1980년대 초반까지 다소 감소하며, 이후 다소 안정된 상태를 보이고 1997, 2008년에 각각 $9.54,10.02$ 로 급증하는 경향을 보인다. Berner and Raiswell (1984)에 의하면 C/S 비율은 해양퇴 적물에서 $0.5 \sim 5$, 담수퇴적물에서 10 이상의 비율로 나타 난다고 알려져 있다. 그리고 산소농도가 낮아질 때 $\mathrm{C} / \mathrm{S}$ 비 율이 감소한다(Tsujimoto et al. 2008). 본 연구에서 1965 년부터 1980년 초반까지 $\mathrm{C} / \mathrm{S}$ 비율이 감소하는 현상은 퇴 적물 내 산소가 감소하여 빈산소층으로 진행되는 과정을 나타내고 있는 것으로 생각된다.

이상과 같은 분석 결과, 가막만 북측해역 퇴적물은 1977년 이전에는 주로 육원성 퇴적물이 집적되었으나 1977년 이후 질소 농도가 급증하며 부영양화가 진행되어 식물 플랑크톤 등과 같은 부유생물들이 급증, 사후 대량집 적에 따른 퇴적층의 빈산소 현상이 진행되는 일련의 과정 을 나타내고 있는 것으로 해석된다. 가막만 북측해역 퇴적 물에서 부영양화현상에 의한 퇴적물 집적은 1977년 이후 본격적으로 발생한 것으로 해석되며, 이후 형성된 저산소 또는 빈산소 퇴적층 두께는 약 $20 \mathrm{~cm}$ 에 달한다.

\section{저서성 유공충 종조성과 빈산소 퇴적층과의 상관성}

주상시료의 총 14 개 정점 $(2 \mathrm{~cm}$ 간격 $)$ 에서 사질(agglu- 


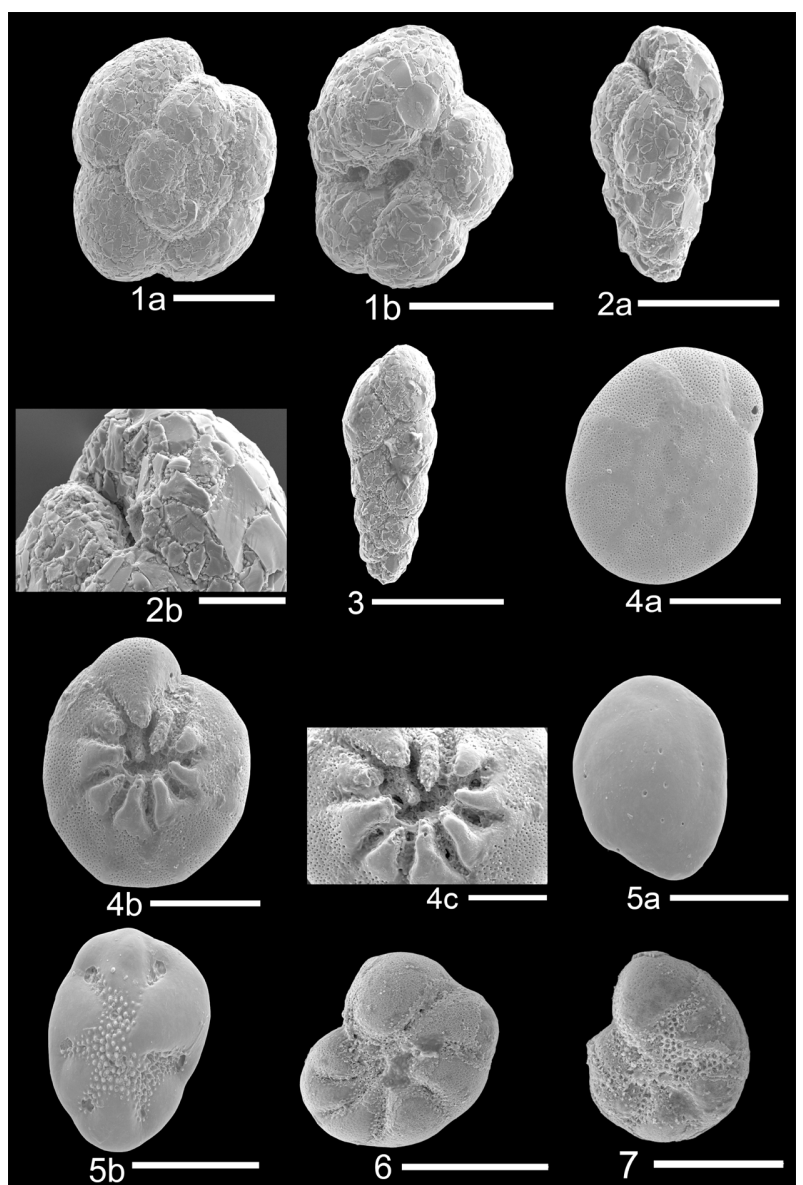

Fig. 6. Scanning electron micrographs of the dominant benthic foraminifera from core K-1, scale: 200 $\mu \mathrm{m}$ (2b, $50 \mu \mathrm{m} ; 4 \mathrm{c}, 100 \mu \mathrm{m})$. Note, 1a, b, Trochammina hadai Uchio; 2a, b, 3, Eggerella advena (Cushman); 4a, b, c. Ammonia beccarii (Linné); 5a, b. Buccella frigida (Cushman); 6, 7, Elphidium subarcticum Cushman

tinated) 유공충 3속 3종, 석회질-유리상(calcareous-hyaline) 유공충 10속 17종 및 석회질-자기상(calcareous-porcelaneous) 유공충 2속 3종, 저서성 유공충 총 16 속 24종을 분류하였 다(Appendix 1). 14 개 정점 중 최소 1 개 이상 정점에서 $10 \%$ 이상 산출하는 우점종은 Trochammina hadai, Eggerella advena, Ammonia beccarii, Buccella frigida, Elphidium subaricticum 등 5종이다(Fig. 6). 이들의 산출 량 변화를 보면, A. beccarii(Fig. 7b)는 1965년 이후부터 1980년까지 45.5 65.9\%로 높게 나타나나 1980년 이후부 터 2008년까지 0 9.7\%로 급감하여 매우 낮게 나타나고 있다. B. frigida(Fig. 7c)는 A. beccarii와 거의 같은 산출 빈도 변화양상을 보인다. T. hadai(Fig. 7a)는 1965년부터 1980년까지 2.8 14.2\%로 매우 낮게 나타나나, 1980년 이 후 증가하기 시작하여 1987 년에는 $98.8 \%$ 에 달한다. 이러 한 높은 산출빈도는 1994년 중반까지 지속되나 1997년
$30.9 \%$ 까지 급감했다가 이후 2000년부터 2008년까지 다시 $90 \%$ 전후의 높은 산출빈도를 보인다. E. advena(Fig. 7d) 는 최근 2008 년에 $11.7 \%$ 로 다소 높게 나타나고 있다. $E$. subaricticum(Fig. 7e)는 1980년 초반과 1997년에 38.5\%, $42.8 \%$ 로 각각 높게 나타나고 있다. 이상 5 개 우점종 중 가 장 높은 산출빈도를 보이는 A. beccarii 및 B. frifida와 $T$. $h a d a i$ 의 산출빈도 변화 형태는 역의 상관관계를 가지는 것을 알 수 있다. 그리고 1997 년에 T. hadai의 산출빈도는 급감하나 A. beccarii, B. frigida 및 E. subaricticum 산출 빈도는 증가하며, 이러한 증가형태는 E. subaricticum에서 특히 뚜렷이 나타난다.

유공충 군집 분석에서 총 산출량, 종다양도 및 균등도 등은 서식환경 변화에 대한 스트레스를 추정하는 척도로 서 넓게 사용된다. 주상시료 K-1의 저서성 유공충 종다양 도는 1965년-1985년까지 다양도 지수 1.5 이상으로 나타 나나 이후 급감한다(Fig. 7f). 그리고 1997년에 일시적으 로 급증하나 전반적으로 낮게 나타나고 있다. 이러한 변화 양상은 균등도에서도 거의 같이 나타나고 있다(Fig. $7 \mathrm{~g}$ ). 저서성 유공충 총 산출량 변화를 보면, 약 1966년경에는 개체수가 1904개체로 가장 높은 산출빈도를 보이나 이후 서서히 감소하는 경향을 보이며 1980년 초 이후에는 12 개 체까지 급감하는 경향을 보인다(Fig. 7h). 이러한 낮은 산 출빈도는 2000년 초까지 진행되었으며 이후 2008년에 다 소 높게 나타난다.

각 깊이별 구성종을 대상으로 한 cluster analysis 결과, 3 개 cluster(cluster I III)가 형성된다(Fig. 8). cluster I은 깊이 0 6, 8 14 cm에 분포하며 주로 $T$. hadai로 구성된다. cluster II는 깊이 6 8, 14 18 cm에 분포하며 주로 $T$. hadai, B. frigida, E. subaricticum으로 구성된다. cluster III는 깊이 $18 \sim 28 \mathrm{~cm}$ 에 분포하며 주로 $A$. beccarii, $B$. frigida 및 E. subaricticum으로 구성된다. cluster $\mathrm{I}$ 과 cluster III는 종조성에 있어서 확실히 대비되나 cluster II 는 cluster I과 III의 혼합 종조성 양상을 보인다. 각 저서 성 유공충 군집과 형성연대를 보면, cluster I은 1987년 이 후부터 2008년에 형성된 퇴적층을 대표하는 T. hadai 군 집, cluster II는 1980년부터 1987년 사이에 형성된 퇴적층 을 대표하는 T. hadai-B. frigida 군집, 그리고 cluster III는 1967년부터 1980년 사이에 형성된 퇴적층을 대표하는 $A$. beccarii-B. frigida 군집이다.

이상의 결과를 종합하면(Fig. 9), 1967년부터 1980년의 A. beccarii-B. frigida 군집 퇴적층은 1977년경 $\mathrm{PON}$ 함량 이 급증하기 전까지 $0.02 \sim 0.08 \mathrm{mgN} / \mathrm{g}$-dry로 매우 낮고, $\mathrm{C} / \mathrm{N}$ 비율도 육원성 기원 퇴적물을 지시하며, $\mathrm{C} / \mathrm{S}$ 비율에 서도 부영양화에 의한 빈산소 이전의 단계를 지시하고 있 다. 주 구성종인 A. beccarii는 조간대 및 조하대에 넓게 분포하며, 하구역이나 담수의 영향을 받는 기수성 환경에 
(a)

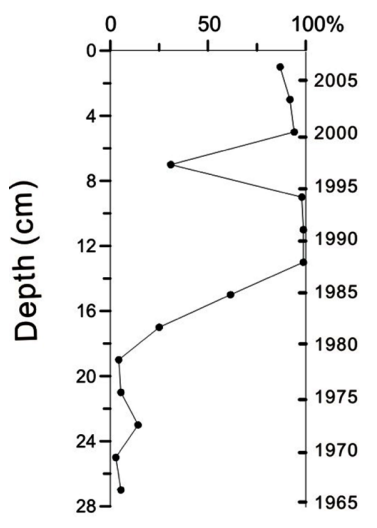

(e)

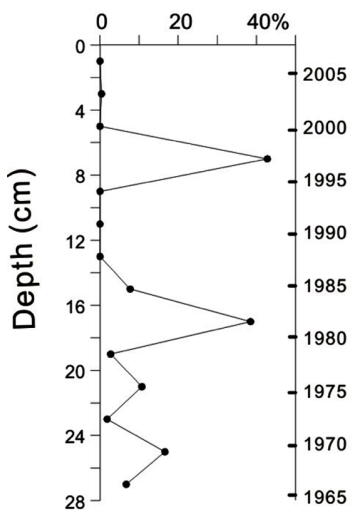

(b)

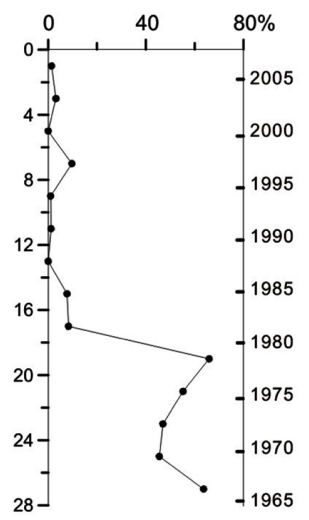

(f)

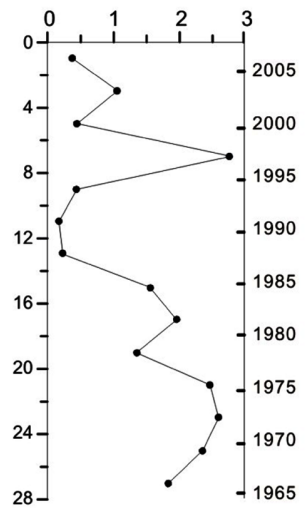

(c)

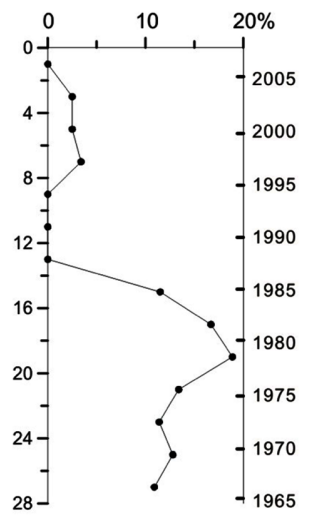

(g)

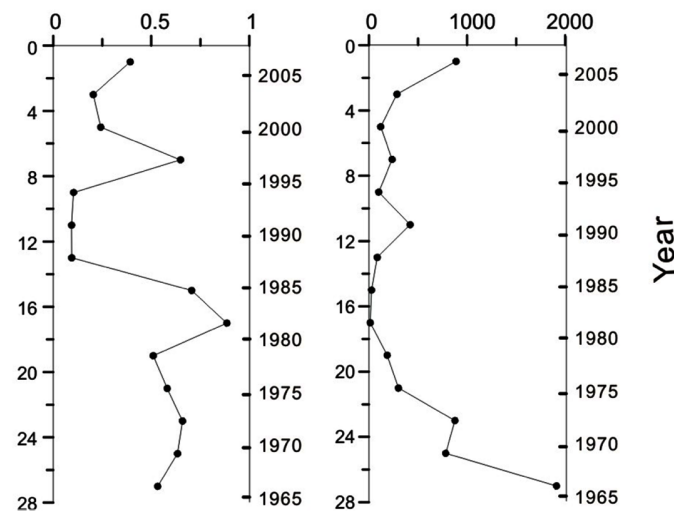

(d)

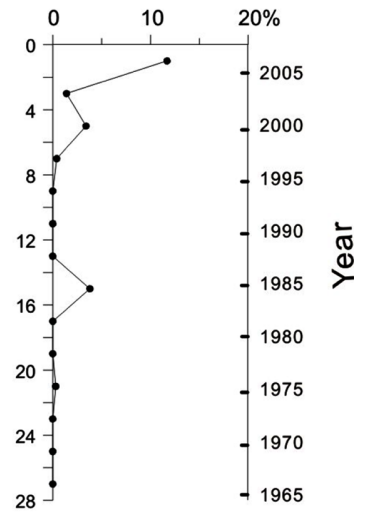

(h)

$\stackrel{\stackrel{\varpi}{\infty}}{\stackrel{\varpi}{\infty}}$

Fig. 7. Temporal variations of the dominant benthic foraminifera species (a: T. hadai, b: A. beccarii, c: B. frigida, d: $E$. advena, e: E. subarcticum) and statistical analysis (f: diversity, g: eveness, h: abundance)

서도 우점하는 종이다(Murray 1991; Moodley and Hess 1992; Alve and Murray 1999; Nomura and Seto 2002; Hayward et al. 2004). 한국의 서해 조간대 퇴적층 및 남 해 조간대 퇴적층에서도 일반적으로 매우 풍부하게 산출 하는 종으로 알려져 있다(Cheong 1989; Lee et al. 2000; 우와 이 2006; 우 2007). B. frigida 역시 담수의 유입이 활발한 내만 환경에서 주고 서식하는 종이다(Matoba 1970; Kato 1986). 따라서 A. beccarii-B. frigida 군집은 1967년부터 1980년 이전 부영양화가 발생하기 전의 내만 해역 환경을 대표하는 저서성 유공충 군집으로 해석된다.

1987년 이후부터 2008년 사이 시기는 T. hadai 군집으 로 대표된다. 이 시기는 $\mathrm{PON}, \mathrm{C} / \mathrm{N}$ 분석결과, 부영양화가 지속적으로 진행되어온 시기이다. 이 군집에서는 저서성 유공충 산출량, 종다양도 및 균등도가 매우 낮게 나타나며 (Fig. 7f, g), T. hadai 가 전체 산출량의 $90 \%$ 이상을 차지 한다(Fig. 7a). 일반적으로 오염원에서 일정거리 떨어진 주변해역에서는 유기물의 증가로 인하여 먹이가 풍부해지 고 상대적으로 포식자의 수가 줄어들면서 유공충의 산출
량이 증가하는 양상을 보이기도 한다. 그러나 직접적인 오 염의 영향을 받는 환경에서는 부영양화와 빈산소 환경의 형성으로 인하여 유공충의 산출량이 매우 적거나 거의 산 출되지 않는 해역(abiotic zone, Alve 1995a), 특히 양식장 에 의해 오염된 환경에서는 이러한 경향이 뚜렷한 것으로 보고되어 있다(Yanko et al. 1999). T. hadai 군집에서 저 서성 유공충의 산출량이 매우 적은 것은 이 해역이 양식 장이라는 오염원의 중심에 위치하고 있기 때문으로 해석 된다. 지속적인 유기물의 유입으로 인하여 해저에 빈산소 환경이 형성되면 저서성 유공충의 종다양도는 감소하며 특정 기회종의 개체수는 증가하게 된다(Tsujimoto et al. 2006, and references therein). T. hadai는 미국 일본 등지 의 유기물 함량이 높은 기수역에 우점하는 종으로, 부영양 화에 의한 오염이 진행됨에 따라 서식밀도가 증가하는 사 질 유공충으로 알려져 있다(Nomura and Seto 2002; Nomura 2003). 특히, E. advena와 함께 오사카만(Osaka $\mathrm{Bay})$ 에서 부영양화에 의한 빈산소 퇴적층의 대표적인 유 공충 군집으로 보고되어 있다(Tsujimoto et al. 2006a, 


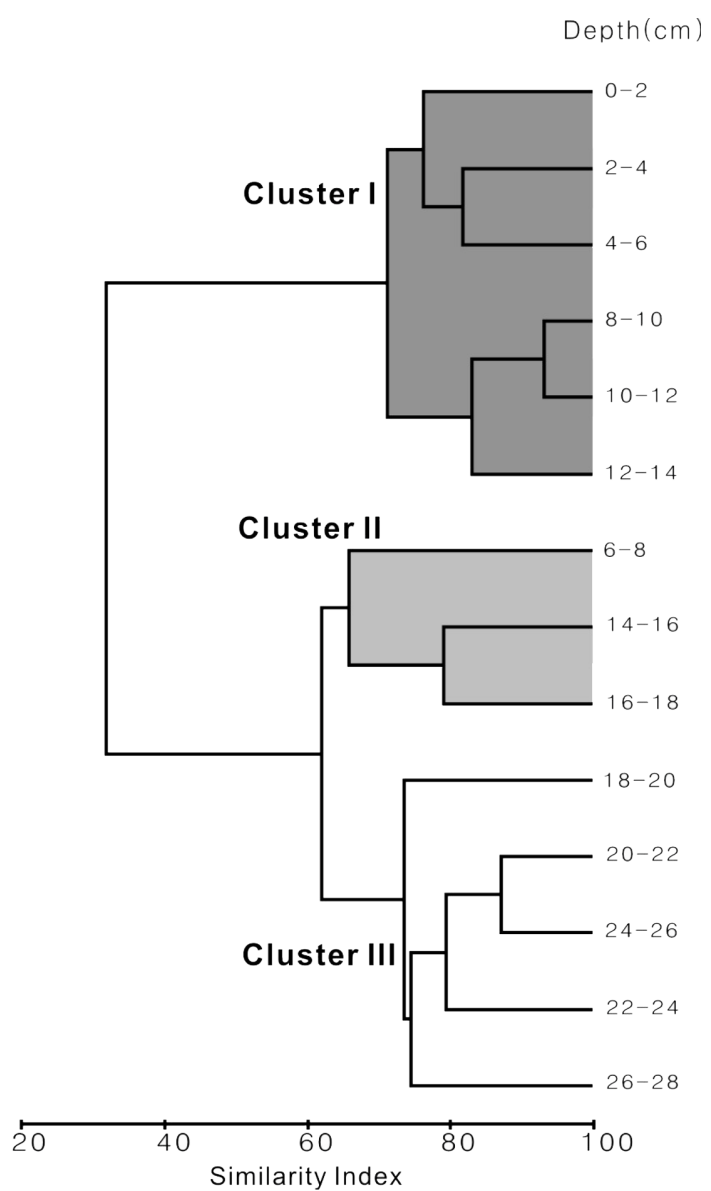

Fig. 8. Dendrogram resulting from cluster analysis on the basis of the Bray Curtis similarity index (SI) between each sampling depth of core K-1 2006b, 2008). 군집의 상부(2005년 이후)에서 E. advena가 다소 높은 빈도 $(11.7 \%)$ 로 산출한다. E. advena는 세계적 으로 하수오염 해역에서 특징적으로 보고되어 있는 종이 다(Alve 1995a, 1995b; Culver and Buzas 1995; Tshjimoto et al. 2008). 그러나 K-1 주상시료에서는 2005년 이전에 는 산출량이 매우 미미하며, 2008년 이후의 산출 양상도 현재로서는 추론할 수 없는 상황이다. 따라서 2005년 이 후 E. advena의 산출 경향 및 원인에 대해서는 향후 지속 적인 모니터링을 통한 연구가 필요한 것으로 사료된다.

A. beccarii-B. frigida 군집과 T. hadai 군집 사이에는 $T$. hadai -B. frigida 군집(1980년 1987년)이 분포한다. 이 군 집은 A. beccarii-B. frigida 군집과 T. hadai 군집의 혼합 군집으로서 빈산소 퇴적층이 형성되는 초기단계를 나타 내는 전이적 성격을 가지는 저서성 유공충 군집으로 해 석된다.

코아 퇴적물의 저서성 유공충 군집을 이용한 연구에서 오염 이전과 최대 오염 시기까지의 과정을 살펴보면, 오염 의 초기부터 최대 오염 이전까지는 오염 이전에 형성된 자연적인 군집이 서서히 감소하여 거의 소멸되며, 오염 지 시 군집은 오염 초기에 급증하여 최대 오염 시기 직전에 최대량을 나타낸다. 그리고 이들 사이에 전이 군집이 서서 히 증가했다가 사라지는 양상을 보인다(Alve 1995). 본 연 구에서도 세 군집 사이의 이러한 양상이 뚜렷이 보인다. 주상시료의 분석 결과, 1977 년부터 부영양화가 진행되었 으며, 이로 인하여 빈산소 퇴적물이 형성되기 시작하고 유 공충 종조성 변화가 시작된다. 이 시기에는 부영양화 이전 의 군집(A. beccarii-B. frigida 군집)이 감소하고 전이 군
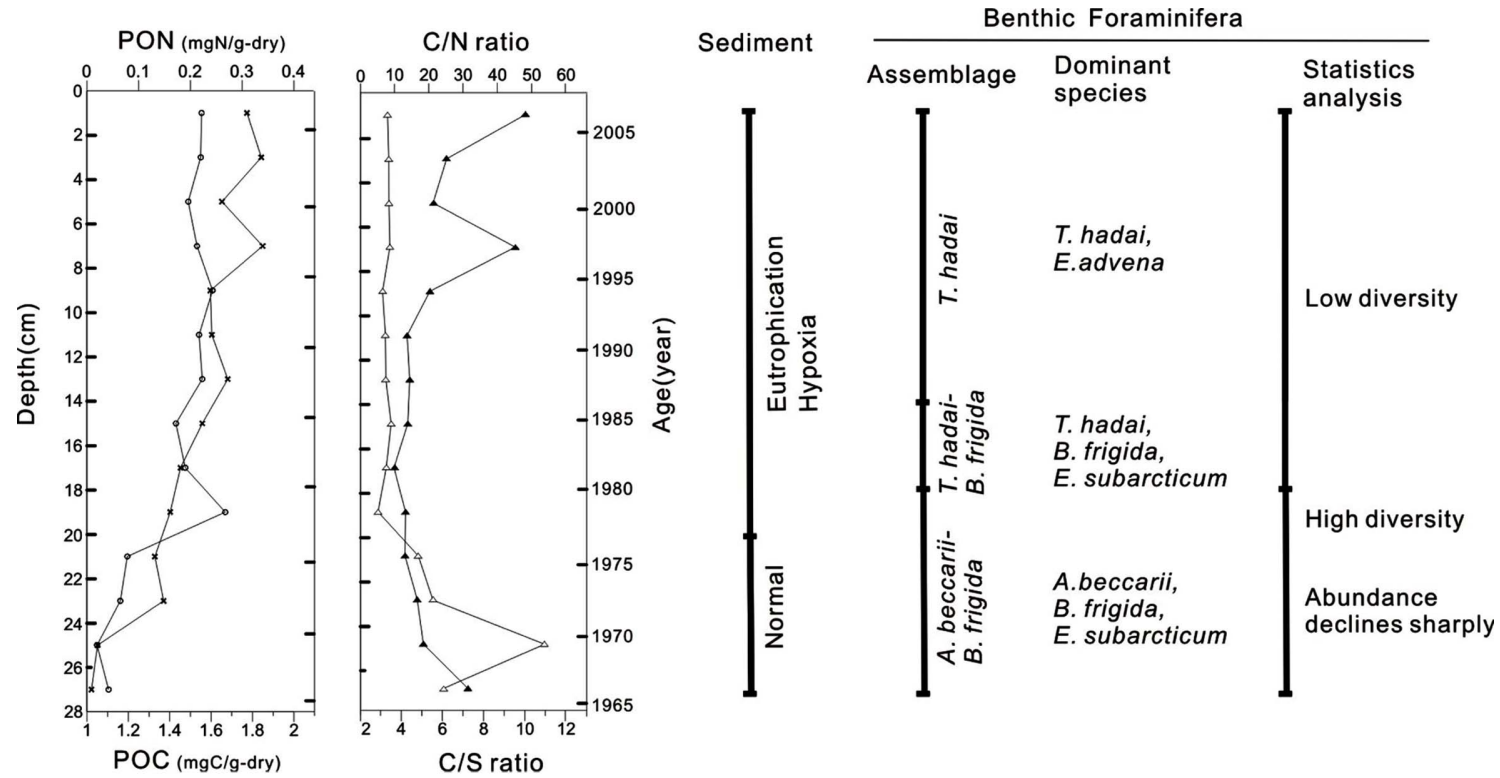

Fig. 9. Synthesize comparison analysis between $\mathrm{PON}, \mathrm{C} / \mathrm{N}, \mathrm{C} / \mathrm{S}$ and benthic foraminifera assemblage. Note, PON, open circle; $\mathrm{C} / \mathrm{N}$, open triangle; $\mathrm{C} / \mathrm{S}$, black triangle 
집(T. hadai-B. frigida 군집)이 형성되며, 기회종(T. hadai) 이 증가한다. 1987 년 이후에는 거의 기회종으로 구성되는 군집(T. hadai 군집)을 형성하고 있다.

1997 년에 일시적으로 $\mathrm{C} / \mathrm{S}$ 와 저서성 유공충의 종다양도 가 급증하며, E. subaricticum의 산출빈도가 높게 나타난 다. 황(S)은 퇴적물 유기오염의 누적지표로 이용되는 인자 로서 $\mathrm{C} / \mathrm{S}$ 급증은 퇴적물 유기오염 정도가 낮아졌음을 뜻 한다. 그리고 일반적으로 Elphidium 속은 외해수의 영향 을 많이 받는 해양환경에 서식하는 종으로 알려져 있으 며, 종 다양도가 급증하는 것은 서식환경이 일시적으로 좋 아졌다는 것을 지시하고 있다. 즉 해수흐름이 매우 미약하 고 거의 정체된 상태를 보이는 가막만 북측해역(Lee and $\operatorname{Kim} 2009)$ 의 빈산소 퇴적층에서 일시적으로 해양환경이 좋아졌음을 나타내고 있다. 가막만 북측해역 저질환경의 호전 현상은 어장정화사업에 의한 준설 영향을 생각할 수 있으나, 강우 및 양식어업활동 변화 등 여러 다른 요인과 의 상관성에 대한 추후 검토를 할 필요가 있다.

\section{5. 결 론}

가막만 북측해역에서 채취한 주상시료 퇴적물의 지화학 및 저서성 유공충 군집 변화를 연구한 결과, 가막만 북측 해역 퇴적물은 1977년 이후 부영양화가 진행되어 빈산소 퇴적층이 형성되는 일련의 과정을 기록하고 있는 것으로 해석된다. 가막만 북측해역 퇴적물에서 부영양화현상에 의한 퇴적물 집적은 1977년 이후 본격적으로 발생한 것으 로 해석되며, 이후 형성된 저산소 또는 빈산소 퇴적층 두 께는 약 $20 \mathrm{~cm}$ 에 달한다. 1980년 이후 부영양화 이전의 군집(A. beccarii-B. frigida 군집)이 감소하고 전이 군집( $T$. hadai-B. frigida 군집)이 형성되며, 기회종(T. hadai)이 증 가한다. 1987 년 이후에는 거의 기회종으로 구성되는 군집 (T. hadai 군집)을 형성하고 있다. T. hadai 군집에서는 저 서성 유공충의 산출량 및 종다양도가 매우 낮게 나타나는 데, 이러한 특성은 오염원의 중심에 위치하는 해역의 전형 적인 군집양상을 보여주는 것으로 해석된다. 가막만 북부 해역에서 T. hadai는 유기물 오염 지시자로 생각되며, 주 변 해역에 대한 확대 적용 가능성에 대해서는 추후 다른 해역에 대한 비교, 검토가 필요한 것으로 사료된다.

\section{사 사}

본 연구를 수행하는데 많은 도움을 주신 한국해양연구 원 조진형 박사에게 감사를 드립니다. 또한 논문을 위해 유익한 조언을 주신 익명의 심사위원께 감사드립니다. 이 논문은 2009년 정부(교육과학기술부)의 재원으로 한국연 구재단의 지원을 받아 수행된 연구입니다(2009-0073535).

\section{참고문헌}

김동선, 김상우 (2003) 진동만의 빈산소수괴 형성기구. 한국 해양학회지 「바다」 8:177-186

김정배, 이상용, 유준, 최양호, 정창수, 이필용 (2006) 가막만 빈산소 수괴의 특성. 한국해양환경공학회지 9(4):216-224

노일현, 윤양호, 김대일, 박종식 (2006) 가막만 표층퇴적물중 유기물의 시 · 공간적 분포 특성. 한국해양환경공학회지 9:1-13

문성용, 서호영, 최상덕, 정창수, 김숙양, 이영식 (2006) 가막 만 동물플랑크톤의 수층 분포에 미치는 저산소화의 영향. 환경생물학회지 24:240-247

오석진, 박종식, 윤양호, 양한섭 (2009) 북부 가막만의 식물플 랑크톤 군집 변동 해석. 해양환경안전학회 15:329-338

우한준 (2007) 강진만 표층 퇴적물의 저서성 유공충 분포 특 성. 한국고생물학회지 23:1-13

우한준, 김효형, 정갑식, 천종화, 김성은, 추용식 (1999) 마산 만 퇴적환경 오염에 따른 저서성 유공충 분포 변화. 한국 해양학회지 「바다」4:144-154

우한준, 정갑식, 권수재, 추용식, 김효영, 박성민 (2000) 대산 유화학단지 주변의 저서성 유공충 분포 특성. 고생물학회 지 16(2):99-112

우한준, 이연규 (2006) 강화 남부 갯벌의 유공충 특성. 한국 습지학회지 8:51-65

윤양호 (2010) 바다의 반란 적조. 집문당, 서울, $531 \mathrm{p}$

이연규, 황진연, 정규귀 (1995) 가막만 표층퇴적물 특성 및 점토광물. 한국지구과학회지 16:477-488

Alve E (1995a) Benthic foraminiferal responses to estuarine pollution: a review. J Foramin Res 25:190-203

Alve E (1995b) Benthic foraminiferal distribution and recolonization of formerly anoxic environments in Drammensfjord, southern Norway. Mar Micropaleontol 25:169-186

Alve E, Murray JW (1999) Marginal marine environments of the Skagerrak and Kattegat: a baseline study of living(stained) benthic foraminiferal ecology. Palaeogeogr Palaeocl 146:171-193

Amstrong HA, Brasier MD (2005) Microfossils. Second Edition. Blackwell Publishing, UK, 296 p

Arai MN (2001) Pelagic coelenterates and eutrophication: a review. Hydrobiologia 451:69-87

Asano K (1950a) Illustrated Catalogue of Japanese Tertiary smaller Foraminifera. Part 1: Nonionidae. Hosokawa Printing Co, Tokyo, Japan, $12 \mathrm{p}$

Asano K (1950b) Illustrated Catalogue of Japanese Tertiary smaller Foraminifera. Part 2: Buliminidae. Hosokawa Printing Co, Tokyo, Japan, $19 \mathrm{p}$

Asano K (1950c) Illustrated Catalogue of Japanese Tertiary smaller Foraminifera. Part 3: Textulariidae. Hosokawa 
Printing Co, Tokyo, Japan, 7 p

Asano K (1950d) Illustrated Catalogue of Japanese Tertiary smaller Foraminifera. Part 4: Valvulinidae. Hosokawa Printing Co, Tokyo, Japan, $4 \mathrm{p}$

Asano K (1950e) Illustrated Catalogue of Japanese Tertiary smaller Foraminifera. Part 5: Verneuilinidae. Hosokawa Printing Co, Tokyo, Japan, $4 \mathrm{p}$

Berner RA, Raiswell R (1984) C/S method for distinguishing freshwater from marine sedimentary rocks. Geology 12: 365-368

Boesch DF, Brinsfield RB, Magnien RE (2001) Chesapeake Bay eutrophication: scientific understanding, ecosystem restoration, and challenges for agriculture. J Environ Qual 30:303-320

Bordowskiy OK (1965a) Accumulation of organic matter in bottom Sediments. Mar Geol 3:33-82

Bordowskiy OK (1965b) Sources of organic matter in marine basins. Mar Geol 3:5-31

Cheong HK (1989) A study on the benthic foraminifera from the tidal flats adjacent to Inchon, Korea. J Paleont Soc Kor 5:39-52

Cloern JE (2001) Our evolving conceptual model of coastal eutrophication problem. Mar Ecol Progr Ser 210:223-253

Culver SJ, Buzas MA (1995) The effects of anthropogenic habitat disturbance, habitat destruction, and global warming on shallow marine benthic foraminifera. J Foramin Res 25:204-211

Diaz RJ, Rosenberg R (1995) Marine benthic hypoxia: a review of its ecological effects and the behavioral responses of benthic macrofauna. Oceanogr Mar Biol Ann Rev 33:245-303

Ernst SR, Morvan J, Geslin E, Le Bihan A, Jorissen FJ (2006) Benthic foraminiferal response to experimentally induced Erika oil pollution. Mar Micropaleontol 61:7693

Folk RL (1968) Petrology of the sedimentary rocks. Hemphills, Austin, Texas, $170 \mathrm{p}$

Frontalini F, Coccioni R (2008) Benthic foraminifera for heavy metal pollution monitoring: a case study from the central Adriatic Sea coast of Italy. Estuar Coast Shelf Sci 76:404-417

Gray JS (1992) Eutrophication in the sea. In: Columbo G, Ferrari I, Ceccherelli VU, Rossi R (eds) Marine eutrophication and population dynamics. Olsen and Olsen, Fredensborg, pp 3-15

Gray JS, Wu RSS, Or YY (2002) Effects of hypoxia and organic enrichment on the coastal marine environment. Mar Ecol Progr Ser 238:249-279

Hanazato T (1997) Development of low-oxygen layer in lake and its effect on zooplankton commnities. Kor J Limnol 30:506-511

Hayward BW, Sabaa A, Grenfell HR (2004) Benthic foraminifera and the late Quaternary (last 150ka) paleoceanographic and sedimentary history of the Bounty Trough, east of Newzealand. Palaeogeogr Palaeocl 211:59-93

Hong JS (1987) Summer oxygen deficiency and benthic biomass in the Chinhae bay system, Korea. J Kor Soc Oceanogr 22:246-256

Ingram RL (1971) Sieve analysis. In: Carver RE (ed) Process in sedimentary petrology. Willey-Inter Science, pp 49-67

Kang CK, Lee PY, Park JS, Kim PJ (1993) On the distribution of organic matter in the nearshore surface sediment of Korea. Bull Kor Fish Soc 26(6):557-566

Kang SR (2003) Benthic Foraminiferal Biostratrgraphy and Paleoenvironments of the Seogwipo Fromation, Jeju Island, Korea. Ph.D. Thesis, Pusan Nationl University, $231 \mathrm{p}$

Kang SW (1991) Circulation and pollutant dispersion in Masan-Jinhae Bay of Korea. Mar Pollut Bull 23:37-40

Lee MO, Kim BK (2009) Wind effects on tidal currents in Gamak Bay. J Ocean Eng Tech 23:18-27

Lee YG, Chu YS, Jung KK, Woo HJ, Lee HJ (2000) Depositional processes of fine-grained sediments and foraminiferal imprint of estuarine circulation by Summer floods in Yoja Bay, Southern Coast of Korea. J Kor Soc Oceanogr 35:109-123

Lim HS, Diaz RJ, Hong JS, Schaffner LC (2006) Hypoxia and benthic community recovery in Korean coastal waters. Mar Pollut Bull 52:1517-1526

Matoba Y (1970) Distribution of Recent Shallow Water Foraminifera of Matsushima Bay, Miyagi Prefecture, Northeast Japan. Sci Rep Tohoku B 42:1-85

Matsumoto E (1981) Research activity on the coastal marine pollution. Chisitsu News 319:52-58

Mojtahid M, Jorissen F, Pearson TH (2008) Comparison of benthic foraminiferal and macrofaunal responses to organic pollution in the Firth of Clyde (Scotland). Mar Pollut Bull 56:42-76

Moodly L, Hess C (1992) Tolerance of infaunal benthic foraminifera for low and high oxygen concentrations. Biol Bull 183:94-98

Morvan J, Cadre VL, Jorissen F, Debenay JP (2004) Foraminifera as potential bio-indicators of the "Erika" oil spill in the Bay of Bourgneuf: field and experimental studies. Aquat Living Resour 17:317-322

Müller PJ (1977) C/N ration in Pacific deep-sea sediments: 
effect of inorganic ammonium and organic nitrogen compounds sorbed by clays. Geochim Cosmochim Ac 41:765-776

Murray JW (1991) Ecology and Palaeoecology of Benthic Foraminifera. Longman Scientific \& Technical, $397 \mathrm{p}$

Murray JW (2006) Ecology and Applications of Benthic Foraminifera. Cambridge University Press, New York, $426 \mathrm{p}$

Murray JW, Alve E (2002) Benthic foraminifera as indicators of environmental change: marginal-marine, shelf and upper slope environments. In: Haslett SK (ed) Quaternary environmental micropalaeontology. Oxford University Press, New York, pp 59-90

Nomura R (2003) Assessing the roles of artificial vs. natural impacts on brackish lake environments: foraminiferal evidence from Lake Nakaumi, southwest Japan. J Geol Soc Japan 109:197-214

Nomura R, Seto K (2002) Influence of man-made construction on environmental conditions in brackish Lake Nakaumi, southwest Japan: foraminiferal evidence. J Geol Soc Japan 108:394-409

Pielou EC (1966) The measurement of diversity in different types of biological collections. J Theor Biol 13:131-144

Platon E, Sen Gupta BK, Rabalaisc NN, Turner RE (2005) Effect of seasonal hypoxia on the benthic foraminiferal community of the Louisiana inner continental shelf: the 20th century record. Mar Micropaleontol 54:263-283

Rabalais NN, Turner RE, Sen Gupta BK, Platon E, Parsons ML (2007) Sediments tell the history of eutrophication and hypoxia in the northern Gulf of Mexico. Ecol Appl 17:129-143

Samir AM, El-Din AB (2001) Benthic foraminiferal assemblages and morphological abnormalities as pollution proxies in two Egyptian bays. Mar Micropaleontol 41: 193-227

Sampei Y, Matsumoto E (2001) $\mathrm{C} / \mathrm{N}$ ratios in a sediment core from Nakaumi lagoon, southwest Japan-usefulness as an organic source indicator. Geochem J 35:189-205

Schafer CT (1973) Distribution of Foraminifera near pollution sources in Chaleur Bay. Water Air Soil Poll 2:219-233

Scott DB, Medioli FS, Schafer CT (2001) Monitering in coastal environments using foraminifera and thecamoebial indicators. Cambridge University Press, $177 \mathrm{p}$

Shannon C E, Weaver W (1949) The mathematical theory of communication. University of Illinois Press, Urbana $125 \mathrm{p}$

Thibodeau B, de Vernal A, Mucci A (2006) Recent eutrophication and consequent hypoxia in the bottom waters of the Lower St. Lawrence Estuary: micropaleontological and geo-chemical evidence. Mar Geol 231:37-50

Thomas E, Gapotchenko T, Varekamp JC, Mecray EL, Buchholz ten Brink MR (2000) Benthic foraminifera and environmental changes in long Island Sound. J Coast Res 16:641-655

Tsujimoto A, Nomura R, Yasuhara M, Yoshikawa S (2006a) Benthic foraminiferal assemblages in Osaka Bay, southwestern Japan: faunal changes over the last 50 years. Paleontol Res 10:141-161

Tsujimoto A, Nomura R, Yasuhara M, Yamazaki H, Yoshikawa S (2006b) Impact of eutrophication on shallow marine benthic foraminifers over the last 150 years in Osaka Bay, Japan. Mar Micropaleontol 60:258268

Tsujimoto A, Yasuhara M, Nomura R, Yamazaki H, Sampei Y, Hirose K, Yoshikawa S (2008) Development of modern benthic ecosystems in eutrophic coastal oceans: the foraminiferal record over the last 200 years, Osaka Bay, Japan. Mar Micropaleontol 69:225-239

Yanko V, Ahmad M, Kaminski M (1998) Morphological deformities of benthic foraminiferal tests in response to pollution by heavy metals: implications for pollution monitoring. J Foramin Res 28:177-200

Yanko V, Arnold AJ, Parker WC (1999) Effect of marine pollution on benthic foraminifera. In: Sen Gupta BK (ed) Modern foraminifera. Kluwer Academic Publishers, Dordrecht, pp 201-216

Received Apr. 6, 2011

Revised Sep. 1, 2011

Accepted Jan. 4, 2012 
Appendix 1. Relative frequency (\%) and statistical analysis of benthic foraminifera from core K-1

\begin{tabular}{|c|c|c|c|c|c|c|c|c|c|c|c|c|c|c|}
\hline Species Depth (cm) & $0 \sim 2$ & $2 \sim 4$ & $4 \sim 6$ & $6 \sim 8$ & $8 \sim 10$ & $10 \sim 12$ & $12 \sim 14$ & $14 \sim 16$ & $\overline{16 \sim 18}$ & $18 \sim 20$ & $20 \sim 22$ & $22 \sim 24$ & $24 \sim 26$ & $26 \sim 28$ \\
\hline \multicolumn{15}{|l|}{ Agglutinated Foram } \\
\hline Ammobaculites exiguus & & & & 0.4 & & & 1.2 & & 7.7 & & & 1.8 & & \\
\hline Eggerella advena & 11.7 & 1.4 & 3.4 & 0.4 & & & & 3.8 & & & 0.3 & & & \\
\hline Trochammina hadai & 86.9 & 91.9 & 94.1 & 30.9 & 98.0 & 98.8 & 98.8 & 61.5 & 23.1 & 4.3 & 5.4 & 14.2 & 2.8 & 5.5 \\
\hline \multicolumn{15}{|l|}{ C.-H. Foram } \\
\hline Ammonia beccarii & 1.4 & 3.2 & & 9.7 & 1.0 & 1.2 & & 7.7 & 7.7 & 65.9 & 55.2 & 47.0 & 45.5 & 63.9 \\
\hline Bolivina robusta & & & & & & & & & & & & & & 0.4 \\
\hline B. striatula & & & & 0.4 & & & & & & & 0.3 & & 0.5 & 0.4 \\
\hline Buccella frigida & & 2.5 & 2.5 & 3.4 & & & & 11.5 & 15.4 & 18.9 & 13.4 & 11.4 & 12.8 & 10.9 \\
\hline Bulimina marginata & & & & 0.8 & & & & & & & & & & \\
\hline Elphidium advenum & & & & 0.4 & & & & & & 1.6 & 2.3 & 2.3 & 1.8 & 3.4 \\
\hline E. clavatum & & 0.4 & & 2.1 & & & & 7.7 & 7.7 & 3.8 & 4.7 & 9.6 & 9.5 & \\
\hline E. incertum & & & & 0.8 & & & & & & 0.5 & 1.3 & 2.7 & 2.0 & \\
\hline E. somaense & & & & 2.5 & & & & & & & 4.0 & 4.1 & 3.8 & 2.9 \\
\hline E. subarcticum & & 0.4 & & 42.8 & & & & 7.7 & 38.5 & 2.7 & 10.7 & 1.8 & 16.6 & 6.7 \\
\hline Elphidium sp. & & & & 0.4 & & & & & & & & 0.5 & 0.5 & 0.4 \\
\hline Fissurina orbignyana & & & & & & & & & & & 0.3 & & 0.3 & \\
\hline Fissurina sp. & & & & & & & & & & & 0.3 & & 0.3 & \\
\hline Glabratella patelliformis & & & & & & & & & & & & & 0.3 & \\
\hline Hanzawaia niponica & & & & & & & & & & & & 0.5 & & \\
\hline Pseudoparrella naraensis & & 0.4 & & & & & & & & & 0.7 & 1.8 & & \\
\hline Pseudorotalia gaimardii & & & & & 1.0 & & & & & & & & & \\
\hline \multicolumn{15}{|l|}{ C.-P. Foram } \\
\hline Quinqueloculina polygona & & & & 1.7 & & & & & & & & 0.5 & & 0.4 \\
\hline Q. seminula & & & & 2.5 & & & & & & & 0.7 & 0.5 & 2.3 & 4.6 \\
\hline Spiroloculina laevigata & & & & 0.4 & & & & & & & 0.3 & 0.9 & 1.0 & \\
\hline Miscellaneous & & & & & & & & & & 0.3 & & 0.5 & & 0.4 \\
\hline Total No. Benthic Foram. & 222 & 285 & 118 & 236 & 98 & 419 & 83 & 26 & 13 & 185 & 299 & 219 & 391 & 238 \\
\hline Agglutinated Foram. ratio (\%) & 98.6 & 93.3 & 97.5 & 31.8 & 98.0 & 98.8 & 100.0 & 65.4 & 30.8 & 4.3 & 5.7 & 16.0 & 2.8 & 5.5 \\
\hline C.-H. Foram. ratio (\%) & 1.4 & 6.7 & 2.5 & 63.6 & 2.0 & 1.2 & 0.0 & 34.6 & 69.2 & 93.5 & 93.3 & 81.7 & 93.9 & 89.1 \\
\hline C.-P. Foram. ratio (\%) & 0.0 & 0.0 & 0.0 & 4.7 & 0.0 & 0.0 & 0.0 & 0.0 & 0.0 & 0.0 & 1.0 & 1.8 & 3.3 & 5.0 \\
\hline Species Number S & 3 & 7 & 3 & 16 & 3 & 2 & 2 & 6 & 6 & 9 & 15 & 16 & 15 & 12 \\
\hline Species diversity H(S) & 0.4 & 1.1 & 0.4 & 2.7 & 0.4 & 0.2 & 0.2 & 1.5 & 1.9 & 1.3 & 2.5 & 2.6 & 2.3 & 1.8 \\
\hline Evenness J & 0.4 & 0.2 & 0.2 & 0.6 & 0.1 & 0.1 & 0.1 & 0.7 & 0.9 & 0.5 & 0.6 & 0.7 & 0.6 & 0.6 \\
\hline No. B. F. / sd. $(20 \mathrm{ml})$ & 888 & 285 & 118 & 236 & 98 & 419 & 83 & 26 & 12 & 185 & 299 & 876 & 782 & 1904 \\
\hline
\end{tabular}

C.-H.=Calcareous-Hyaline, C.-P.=Calcareous-Porcelaneous, B.F.=Benthic Foraminifera, sd.=sediments 